\title{
INVENTARISASI DAN IDENTIFIKASI PENYEBAB PENYAKIT PADA Acacia auriculiformis DI YOGYAKARTA
}

Pathogen inventory and identification for Acacia auriculiformis planted in Yogyakarta

\author{
Nur Hidayati dan Rina Laksmi Hendrati \\ Balai Besar Penelitian dan Pengembangan Bioteknologi dan Pemuliaan Tanaman Hutan \\ Jl. Palagan Tentara Pelajar Km. 15, Purwobinangun, Pakem, Sleman, Yogyakarta, Indonesia \\ email: inunghidayati@yahoo.com
}

Tanggal diterima: 3 Maret 2017, Tanggal direvisi: 17 April 2017, Disetujui terbit: 25 September 2018

\begin{abstract}
Acacia auriculiformis is a fast growing species mostly planted in marginal lands with less intensive in cultivation. Problems found on A. auriculiformis cultivation include disease attacks which then caused a significant economic reduction on the plantation. The aim of this study is to determine causes, intensity and severity of the diseases attacking $A$. auriculiformis plants. The research was conducted on two observation plots, in the nursery and in clonal bank area established in Yogyakarta. Genetic materials planted in the plots were collected from clonally propagated of trees selected in second generation progeny trial of A. auriculiformis established in Wonogiri, Central Java. Observations of disease signs and symptoms in the two plots were undertaken with $100 \%$ plants inventories in rainy and dry seasons. Postulate Koch was then performed on this study to identify the pathogens. The result showed that the powdery mildew caused by Oidium sp. is a dominant disease attacking 100\% A. auriculiformis both in the nursery and on clonal bank areas, occurring not only during the rainy season but also during the dry season. There were also other diseases attacking A. auriculiformis namely black mildew caused by Meliola sp, leaf spot disease caused by Phomopsis sp. and root rot disease caused by Ganoderma steyaertanum.
\end{abstract}

Keywords: Acacia auriculiformis, pathogen, disease incidence, disease severity

\begin{abstract}
ABSTRAK
Acacia auriculiformis adalah salah satu jenis tanaman cepat tumbuh dengan pola budidaya yang relatif mudah dan mampu tumbuh dengan baik pada lahan-lahan marginal kering. Namun demikian masih terdapat permasalahan berkaitan dengan ancaman serangan penyakit yang dapat mengurangi potensi nilai ekonomi tanaman $A$. auriculiformis di hutan tanaman. Tujuan dari penelitian ini adalah mengetahui penyebab penyakit, intensitas dan luas serangan penyakit pada tanaman $A$. auriculiformis. Penelitian dilaksanakan di dua plot pengamatan, yaitu persemaian dan bank klon yang dibangun di Yogyakarta. Materi genetik di dalam plot pengamatan merupakan hasil perbanyakan klon yang dikoleksi dari plot uji keturunan generasi kedua (F2) A. auriculiformis di Wonogiri, Jawa Tengah. Pengamatan tanda dan gejala serangan penyakit dilakukan dengan cara inventarisasi $100 \%$ pada saat musim kemarau dan musim penghujan. Selanjutnya dilakukan uji Postulat Koch untuk mengidentifikasi penyebab penyakitnya. Hasil pengamatan menunjukkan bahwa embun tepung yang disebabkan oleh jamur Oidium sp. adalah penyakit dominan yang menyerang klon A. auriculiformis baik di persemaian maupun di bank klon. Serangan terjadi pada musim kemarau maupun musim penghujan dengan luas serangan sebesar 100\%. Terdapat penyakit lain yang menyerang A. auriculiformis di bank klon yaitu penyakit embun jelaga yang disebabkan jamur Meliola sp, penyakit bercak daun yang disebabkan jamur Phomopsis sp. dan penyakit busuk akar yang disebabkan jamur Ganoderma steyaertanum.
\end{abstract}

Kata kunci: Acacia auriculiformis, penyebab penyakit, intensitas dan luas serangan penyakit

\section{PENDAHULUAN}

Acacia auriculiformis Cunn. ex Benth merupakan tanaman alternatif untuk suplai bahan baku industri hasil hutan yang cepat tumbuh, mudah dibudidayakan, selalu hijau di musim kemarau, memiliki kemampuan trubusan yang tinggi serta dapat tumbuh di lahan marginal kering (Joker, 2000). Tanaman ini termasuk jenis leguminosae yang mempunyai kemampuan untuk memfiksasi nitrogen sehingga dapat membantu dalam merehabilitasi lahan marginal. Penelitian yang dilakukan terhadap 21 spesies di Indonesia pada lahan dengan kondisi kering baik di lapangan maupun pada uji terkontrol, menunjukkan bahwa A. auriculiformis tampil terbaik, sehingga sangat ideal untuk mengantisipasi kondisi 
ekstrim kering yang mungkin ditimbulkan akibat perubahan iklim (Hendrati, Nurrohmah, Susilawati, \& Budi, 2014).

Salah satu permasalahan dalam budidaya A. auriculiformis adalah adanya serangan penyakit, sejak di persemaian sampai tingkat dewasa (Anggraeni \& Wibowo, 2006). Adanya serangan penyakit ini dapat menimbulkan permasalahan karena dapat menyebabkan kerugian secara ekonomi. Menurut Rimbawanto, Tjahjono, dan Gafur (2014), penyakit yang sering ditemui pada budidaya akasia antara lain penyakit bercak daun Passalora (Pseudocercospora), bercak daun Pestalotiopsis dan Phaeotrichoconis, busuk akar yang disebabkan oleh jamur Phellinus noxius, busuk akar yang disebabkan oleh jamur Ganoderma, layu Ceratocystis, embun jelaga, embun tepung, hawar daun yang disebabkan Xanthomonas campestris, karat filodia, layu fusarium, antraknosa. Lebih lanjut disebutkan penyakit lain yang bisa menyerang adalah rebah semai yang disebabkan oleh beberapa jenis jamur seperti Phytium spp., Phytophthora spp., Fusarium spp., dan Rhizoctonia solani. Di Sarawak, rebah semai A. auriculiformis disebabkan oleh infeksi dari Pythium spp. dan Fusarium spp. (Chin, 1995 dalam Old, Lee, Sharma, \& Yuan 2000).

Sebagai antisipasi pencegahan dan penyelamatan dari ancaman serangan dan gangguan penyakit pada tanaman A. auriculiformis, maka diperlukan suatu usaha untuk mendiagnosis penyakit, khususnya patogen yang menyebabkan gangguan pada tanaman. Tujuan dari penelitian ini adalah untuk mengetahui penyebab penyakit, intensitas dan luas serangan penyakit pada tanaman A. auriculiformis di dua plot pengamatan, yaitu persemaian dan bank klon di Yogyakarta.

\section{BAHAN DAN METODE}

\section{A. Waktu dan lokasi}

Penelitian dilaksanakan di dua plot pengamatan, yaitu 1) persemaian dan 2) bank klon yang dibangun di Balai Besar Penelitian dan Pengembangan Bioteknologi dan Pemuliaan Tanaman Hutan di Yogyakarta. Lokasi penelitian berada pada $7^{\circ} 40.211$ 'S dan $110^{\circ} 23.512^{\prime} \mathrm{E}$ di ketinggian $367 \mathrm{~m}$ dpl. Kondisi iklim di sebagian besar wilayah Kabupaten Sleman termasuk tropis basah, hari hujan terbanyak dalam satu bulan 24 hari dan curah hujan sekitar $32 \mathrm{~mm}-699 \mathrm{~mm}$. Kecepatan angin maksimum 6,00 knots dan minimum 3,00 knots, rata-rata kelembaban nisbi udara tertinggi $100 \%$ dan terendah $19,9 \%$. Temperatur udara tertinggi $32^{\circ} \mathrm{C}$ dan terendah $24^{\circ} \mathrm{C}$ (www.slemankab.go.id, 2018).

Waktu penelitian dilaksanakan bulan Januari sampai dengan Februari 2016 pada waktu musim hujan dan bulan Oktober sampai dengan November 2016 pada waktu musim kemarau.

\section{B. Bahan dan alat}

Materi tanaman yang digunakan dalam penelitian ini adalah klon hasil perbanyakan vegetatif beberapa tanaman terpilih di plot uji keturunan generasi kedua (F2) A. auriculiformis di Wonogiri, Jawa Tengah. Pada plot pengamatan di bank klon terdapat 70 tanaman dari 51 klon yang ditanam secara acak. Sedangkan pada plot pengamatan di persemaian terdapat 24 tanaman dari 19 klon yang ditata secara acak. Pengamatan mulai di lakukan pada saat tanaman berumur 5 bulan setelah tanam dengan rata-rata tinggi antara $1-1,5$ meter dan rata-rata diameter antara $2,5-3 \mathrm{~cm}$.

Bahan dan peralatan yang digunakan di laboratorium adalah media PDA (Potato Dekstrose Agar), air steril, alkohol 70\%, alkohol 95\%, laminar air flow, mikroskop, petridish, beaker glass, pinset, dan bunsen.

\section{Prosedur kerja}

Kegiatan yang dilakukan dalam penelitian ini adalah:

a. melakukan inventarisasi $100 \%$ penyakit yang menyerang tanaman di dalam plot pengamatan di persemaian dan di bank klon 
dengan cara mengamati gejala dan tanda penyakit tanaman. Pengamatan dilakukan pada bagian daun, batang dan cabang,

b. melakukan pengamatan luas dan intensitas serangan penyakit di dalam plot pengamatan di persemaian dan di bank klon. Penghitungan luas dan intensitas serangan penyakit menggunakan kriteria dan rumus berikut:

- intensitas serangan penyakit setiap sampel diberi nilai (skor) berdasarkan kenampakan keseluruhan setiap individu tanaman mengunakan modifikasi pedoman dari Alexander dan Barnard (1995) dalam Widyastuti dan Susanti (2014) dengan nilai skor:

$0=$ Sehat (tidak ada gejala dan tanda penyakit).

$1=>0-25 \%$ bagian tanaman menunjukkan gejala dan atau tanda penyakit

$2=\quad>25-50 \%$ bagian tanaman menunjukkan gejala dan atau tanda penyakit

$3=>50-75 \%$ bagian tanaman menunjukkan gejala dan atau tanda penyakit

$4=>75-100 \%$ bagian tanaman menunjukkan gejala dan atau tanda penyakit

- luas serangan $=\frac{\Sigma \text { tanaman terserang }}{\Sigma \text { tanaman diamati }} \times 100 \%$

- intensitas serangan $=\frac{\Sigma(\mathrm{nxv})}{\mathrm{NxV}} \times 100 \%$

dimana :

$\mathrm{n}=$ jumlah tanaman terserang pada kategori tertentu

$\mathrm{v}=$ kategori serangan tertentu (skor)

$\mathrm{N}=$ jumlah tanaman diamati

$\mathrm{V}=$ kategori serangan tertinggi yang digunakan

c. mengisolasi bagian tanaman yang menunjukkan adanya gejala dan tanda terserang penyakit, d. melakukan pengujian Postulat Koch untuk identifikasi patogen dan memastikan bahwa patogen yang diperoleh merupakan penyebab penyakit yang menyerang akor.

\section{HASIL DAN PEMBAHASAN}

\section{A. Serangan patogen di persemaian}

Luas serangan penyakit merupakan persentase tanaman yang sakit dalam suatu populasi tanaman. Sedangkan intensitas serangan penyakit adalah persentase jaringan inang atau organ yang ditutupi oleh gejala atau kerusakan oleh penyakit (Spolti, Shah, Fernandes, Bergstrom, \& Del Ponte, 2015). Hasil pengamatan menunjukkan bahwa hanya penyakit embun tepung yang ditemukan pada A. auriculiformis di persemaian. Pada musim kemarau luas serangan penyakit sebesar $100 \%$ dan intensitas serangan sebesar 38,64\%. Sedangkan pada waktu musim hujan luas serangan penyakit sebesar $100 \%$ dan intensitas serangan meningkat sebesar $78,75 \%$.

Penyakit ini menyerang tanaman baik pada musim kemarau maupun pada musim penghujan. Hasil pengamatan pada musim kemarau menunjukkan tanaman yang terserang penyakit embun tepung ditandai dengan permukaan atas daun tertutup dengan bercak putih yang menyerupai tepung dan akan meluas menutupi seluruh permukaan daun (Gambar 1a dan 1b). Bercak-bercak putih yang seperti tepung tersebut adalah konidiofor dan konidia jamur penyebab penyakit embun tepung (Sumartini \& Rahayu, 2017). Menurut HalfeldVieira dan Nechet (2009), embun tepung yang menyerang tanaman $A$. mangium hanya terdapat pada persemaian dengan lingkungan yang ternaungi. Hal yang sama terjadi pada penelitian ini, tanaman A. auriculiformis yang berada di persemaian berada dalam kondisi yang ternaungi sarlon/paranet, sehingga memungkinkan menjadi penyebab penyakit embun tepung menginfeksi tanaman. Faktor yang mempengaruhi penyakit embun tepung adalah suhu, kelembaban dan sinar matahari 
(Sumartini \& Rahayu, 2017). Menurut Rimbawanto, Tjahjono, dan Gafur (2014), penyakit embun tepung cenderung meningkat pada cuaca hangat dan kering. Namun demikian perlu dicatat di sini bahwa tanaman di persemaian telah dilakukan pemeliharaan rutin melalui penyemprotan fungisida pada musim kemarau sebelum pengamatan dilaksanakan, dan hal ini diduga juga menjadi penyebab lebih rendahnya intensitas serangan penyakit pada musim kemarau dibandingkan pada musim hujan.

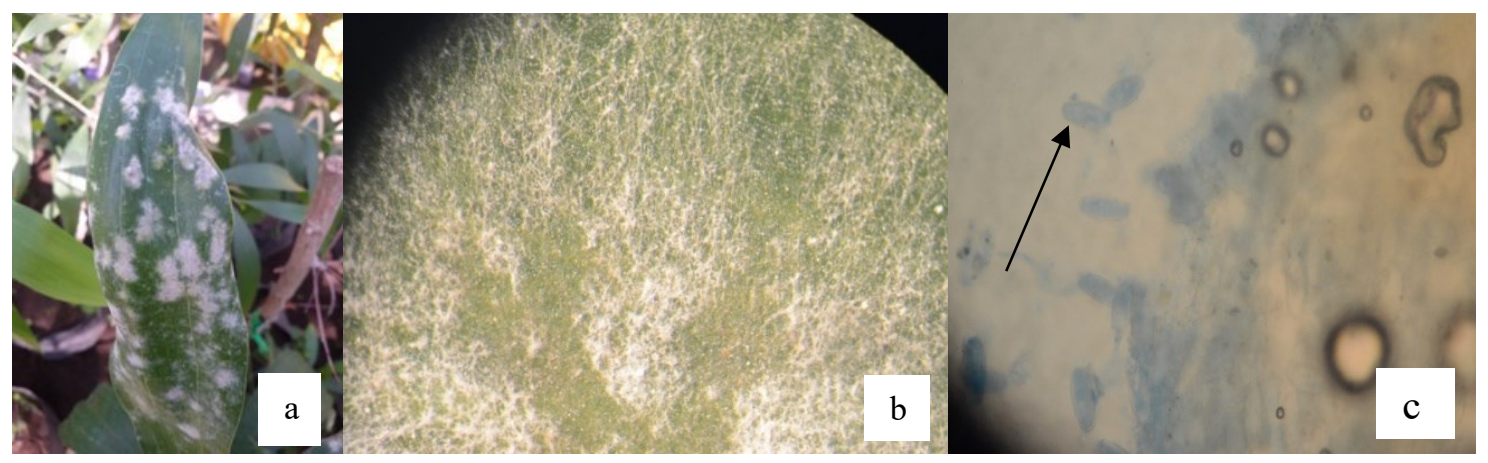

Gambar 1. Daun Acacia auriculiformis yang terdapat tanda penyakit embun tepung berupa lapisan putih (a), Pengamatan lapisan putih pada daun di bawah mikroskop perbesaran $40 \times$ (b). Konidia jamur oidium sp. (tanda panah) yang berada pada daun $A$. auriculiformis yang diambil dari persemaian perbesaran $40 \times(\mathrm{c})$

Hasil identifikasi menunjukkan bahwa jamur penyebab penyakit embun tepung ini adalah jamur Oidium $s p$. Jamur ini bersifat parasit obligat yang tidak bisa dibiakkan dalam media buatan. Spora jamur bertunas di permukaan daun dan menyerang tanaman. Jamur kemudian mengkolonisasi epidermis daun dengan memperoleh nutrisi dari sel tumbuhan tanpa membunuhnya (Cunfer, 2004). Hasil pengamatan mikroskopis ditemukan konidia jamur hialin, tidak bersekat, yang tersusun seperti rantai melekat pada konidiofornya (Gambar 1c). Sel kaki tampak berbentuk silinder dan lobus appressorium. Konidia terbentuk secara tunggal adalah hialin dan ellipsoid. Badan fibrosin tidak ditemukan (Halfeld-Vieira \& Nechet, 2009). Menurut Barnet dan Hunter (1998) konidia jamur dengan ciri-ciri tersebut adalah konidia Oidium sp.

\section{B. Serangan patogen di bank klon}

Pada plot pengamatan di bank klon ditemukan empat jenis penyakit yang menyerang tanaman $A$. auriculiformis, yaitu embun tepung, embun jelaga, bercak daun dan busuk akar. Intensitas dan luas serangan beberapa penyakit yang menyerang tanaman A. auriculiformis pada plot pengamatan di bank klon disajikan pada Tabel 1.

Tabel 1. Luas dan intensitas serangan penyakit yang menyerang tanaman A. auriculiformis di bank klon

\begin{tabular}{|c|c|c|c|c|c|}
\hline \multirow[t]{2}{*}{ No. } & \multirow[t]{2}{*}{$\begin{array}{c}\text { Nama } \\
\text { penyakit }\end{array}$} & \multicolumn{2}{|c|}{$\begin{array}{c}\text { Intensitas } \\
\text { serangan } \\
\text { penyakit }(\%)\end{array}$} & \multicolumn{2}{|c|}{$\begin{array}{c}\text { Luas serangan } \\
\text { penyakit }(\%)\end{array}$} \\
\hline & & kemarau & hujan & kemarau & hujan \\
\hline 1. & $\begin{array}{l}\text { Embun } \\
\text { Tepung }\end{array}$ & 62,69 & 63,45 & 100 & 100 \\
\hline 2. & $\begin{array}{l}\text { Embun } \\
\text { Jelaga }\end{array}$ & 2,9 & 3,8 & 6,46 & 7,7 \\
\hline 3. & $\begin{array}{l}\text { Bercak } \\
\text { Daun }\end{array}$ & 2,76 & 3,5 & 9,2 & 9,2 \\
\hline 4. & $\begin{array}{l}\text { Busuk } \\
\text { Akar }\end{array}$ & - & 0,7 & - & 1,53 \\
\hline
\end{tabular}

\section{Embun tepung (powdery mildew)}

Penyakit embun tepung merupakan penyakit pada tanaman A auriculiformis baik di plot pengamatan di bank klon maupun di persemaian. Luas serangan penyakit embun tepung di bank klon sebesar $100 \%$ baik pada 
musim kemarau maupun pada musim hujan. Adapun intensitas serangan penyakit embun tepung adalah sebesar $62,69 \%$ pada musim hujan dan 63,45 pada musim kemarau. Kondisi daun setelah terserang penyakit embun tepung pada waktu musim hujan sebagaimana disajikan pada Gambar 2a. Namun demikian karena sudah terguyur air hujan, kumpulan konidiofor dan konidia yang meyerupai tepung di permukaan daun tidak teramati.

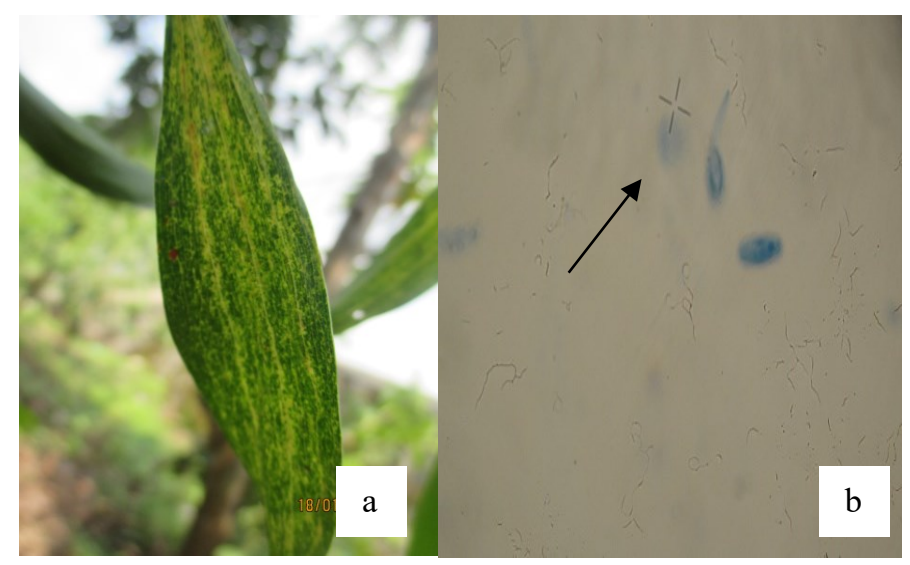

Gambar 2. Daun Acacia auriculiformis di bank klon yang menunjukkan gejala penyakit embun tepung berupa bercak-bercak kuning akibat infeksi dari Oidium spp. (a). Konidia jamur Oidium spp. (tanda panah) pada perbesaran $40 \times($ b)

Intensitas dan luas serangan penyakit embun tepung di bank klon lebih tinggi pada waktu musim kemarau. Hal ini dikarenakan tanaman berada pada lingkungan terbuka sehingga kondisinya relatif lebih banyak mendapat terpaan sinar matahari. Sinar matahari akan sangat berpengaruh terhadap munculnya penyakit embun tepung. Giertych dan Suszka (2010) dalam Sumartini dan Rahayu (2017) menyatakan bahwa pada daerah yang terkena banyak terpaan sinar matahari akan lebih banyak terjadi penyakit embun tepung daripada daerah yang teduh. Keberadaan penyakit ini berpotensi menyebabkan kerugian secara ekonomi apabila berada pada kondisi yang kondusif untuk pertumbuhan dan perkembangan patogen.

\section{Embun jelaga (black mildew)}

Luas serangan penyakit embun jelaga pada tanaman di bank klon pada musim hujan sebesar 7,7\%, dengan intensitas serangan sebesar 3,8\%. Sedangkan pada musim kemarau luas serangan lebih rendah sebesar 6,46\% dengan intensitas waktu serangan $2,9 \%$. Tanda dari tanaman yang terserang patogen ini berupa beledu berwarna hitam merata pada permukaan atas daun yang merupakan koloni dari jamur tersebut (Gambar 3). Menurut Rimbawanto et al., (2014) patogen dari penyakit ini dapat tersebar melalui cipratan air dan serangga serta infeksi lebih sering terjadi pada kondisi lembab. Jamur menutupi permukaan daun secara merata yang akan merugikan karena menghambat metabolisme daun terutama fotosintesis. Menurut Semangun (2000) efeknya akan merambat ke pembentukan bunga/buah yang tidak normal sehingga tanaman tidak berproduksi maksimal. 

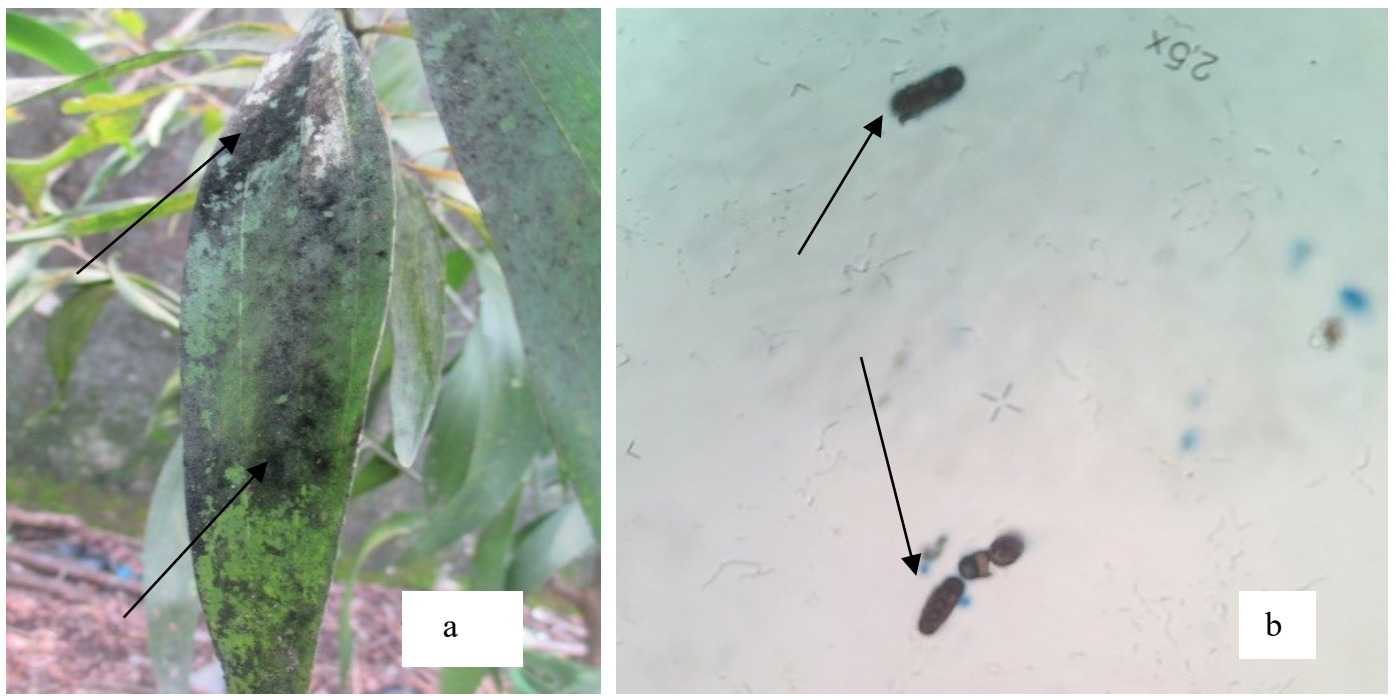

Gambar 3. Daun Acacia auriculiformis yang terdapat tanda penyakit embun jelaga berupa beledu hitam (a). Spora jamur Meliola sp.penyebab penyakit embun jelaga pada perbesaran $40 \times$ (b)

\section{Bercak daun (phomopsis leaf spot)}

Penyakit bercak daun juga ditemukan menyerang pada tanaman $A$. auriculiformis pada plot pengamatan di bank klon. Luas serangan penyakit ini adalah sebesar $9,2 \%$ dengan intensitas serangan sebesar 3,5\% pada waktu musim hujan. Sedangkan pada musim kemarau luas serangan penyakit sebesar $9,2 \%$ dengan intensitas serangan 2,76\%. Gejala tersebut berupa luka berwarna coklat pada ujung daun tanaman A. auriculiformis (Gambar 4a). Hasil identifikasi patogen setelah dilakukan uji Postulat Koch menunjukkan bahwa penyebab penyakit bercak daun ini adalah jamur Phomopsis sp. Menurut Thu et al. (2010), Phomopsis sp. menyebabkan bercak pada daun muda. Penyakit dimulai dari pembentukan luka nekrotik kecil berwarna coklat kemerahan yang kemudian menyatu membentuk luka nekrotik pucat yang lebih luas dan kadang-kadang menambah panjang daun.

Dalam suatu kultur murni (PDA, $25^{\circ} \mathrm{C}$, 12 jam cahaya / $12 \mathrm{~h}$ kegelapan), jamur membentuk miselium putih yang lebih sedikit, yang mengisi cawan petri $(9 \mathrm{~cm})$ dalam 8 hari (Gambar 4b). Sisi belakang berwarna keputihan hingga krem warna dan pada awalnya memiliki bintik-bintik bercak coklat muda, yang kemudian berubah menjadi coklat gelap (Draženka, Karolina, Jasenka, Riccioni, \& Duvnjak, 2007). Lebih lanjut, Draženka et al. (2007) menyebutkan bahawa konidia adalah filiform, lurus atau sedikit melengkung pada satu ujung (Gambar 4c).

\section{Busuk akar (root rot disease)}

Pada plot pengamatan di bank klon ditemukan beberapa tubuh buah jamur Ganoderma sp., yang tumbuh pada tonggak tanaman sebelumnya (Gambar 5). Permukaan atas Ganoderma ini berwarna coklat dan bagian bawahnya berwarna putih. Berdasarkan ciri-ciri morfologisnya, ganoderma yang ditemukan ini merupakan jamur Ganoderma steyaertanum (Hidayati, Glen, Nurrohmah, Rimbawanto, \& Mohammed, 2014). Tubuh buah jamur Ganoderma yang ditemukan ini berada pada kondisi tingkat lanjut. Lapisan pori mempunyai warna yang sama dengan jaringan tubuh buah, pada waktu masih baru warnanya lebih tua dan gelap (Hidayati \& Nurrohmah, 2015). 

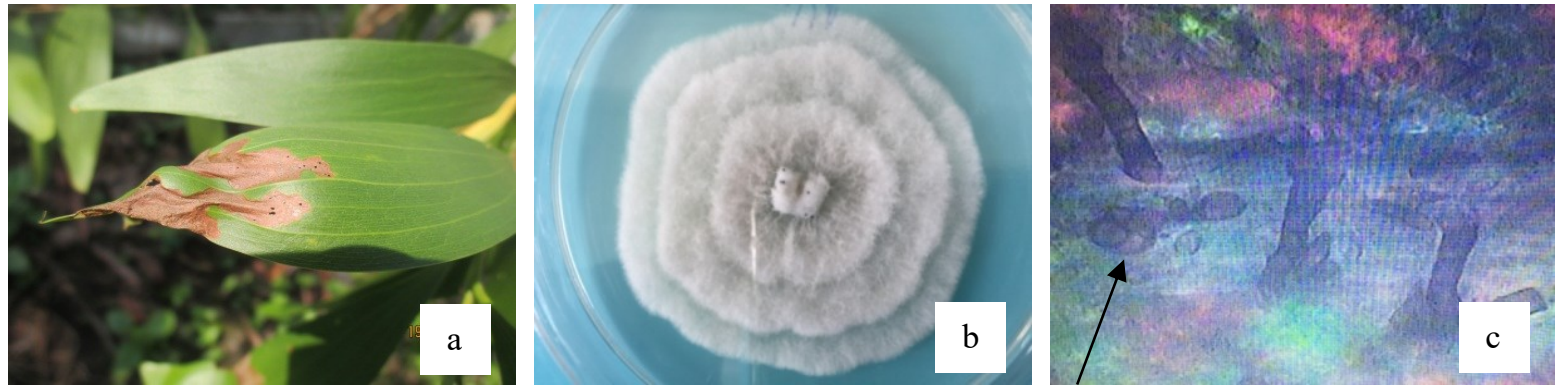

Gambar 4. Daun Acacia auriculiformis yang terinfeksi Phomopsis sp. (a). Isolat jamur Phomopsis sp. Yang diisolasi dari daun $A$. auriculiformis yang menunjukkan gejala serangan patogen. (b). Konidia jamur Phomopsis sp pada perbesaran $40 \times(\mathrm{c})$
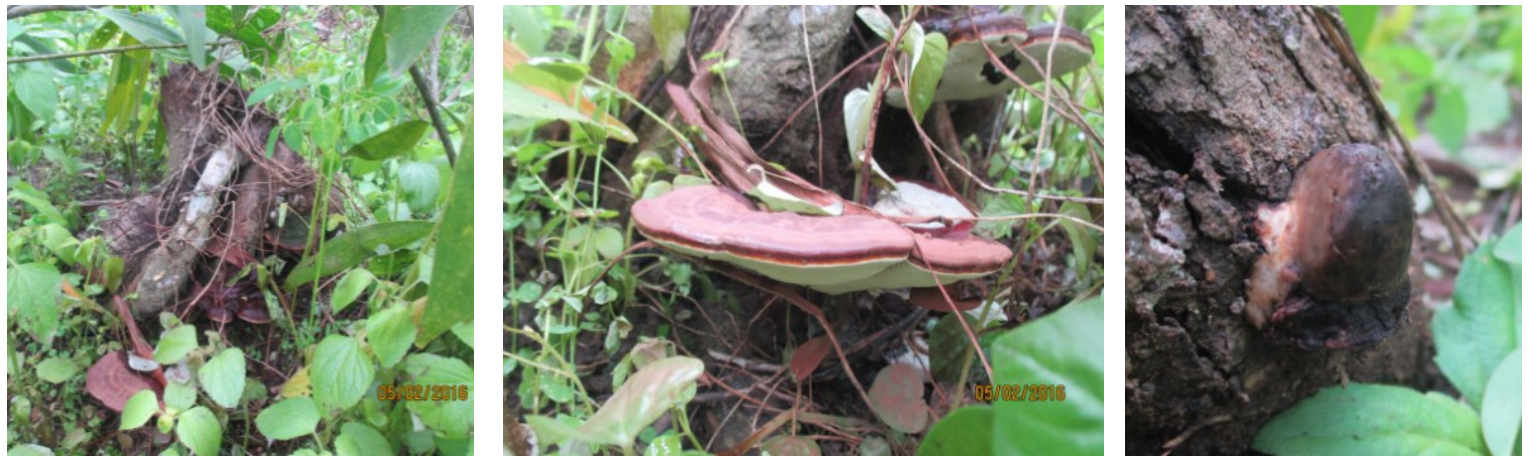

Gambar 5. Beberapa tubuh buah jamur Ganoderma steyaertanum yang ditemukan pada tonggak bekas penebangan tanaman sebelumnya di bank klon $A$. auriculiformis
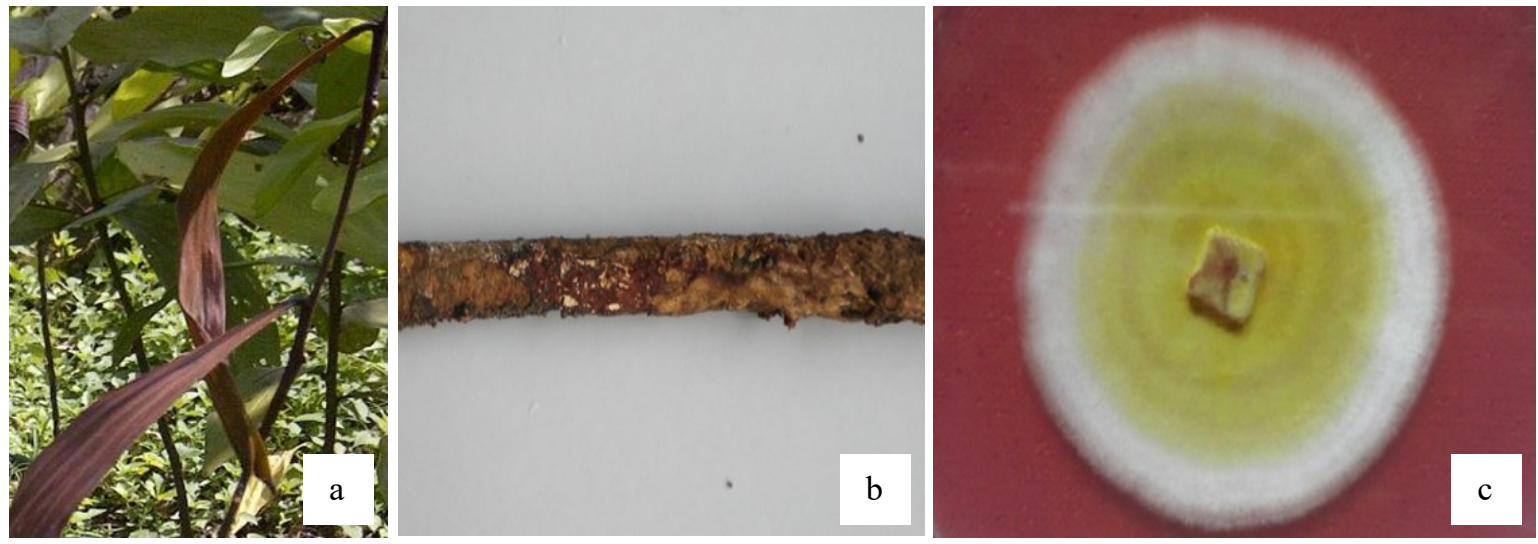

Gambar 6. (a). Daun Acacia auriculiformis yang layu karena penyakit busuk akar (b). Akar A. auriculiformis yang terserang penyakit busuk akar dan (c) Isolat jamur G. steyaertanum penyebab penyakit busuk akar

Walaupun tubuh buah tidak ditemukan pada pangkal batang tanaman A. auriculiformis, beberapa tanaman menunjukkan gejala adanya serangan penyakit busuk akar, seperti daun layu (Gambar 6a) serta ditandai pada akar tanaman terdapat miselia jamur penyebab penyakit (Gambar 6b). Isolat jamur hasil isolasi menunjukkan bagian tengah isolat berwarna kuning (Gambar 6c). Hidayati dan Husna (2015) menyatakan bahwa isolat $G$. steyaertanum pada awal pertumbuhannya, miselium berwarna putih kemudian akan berubah menjadi kuning kecoklatan di bagian tengah yang pertumbuhannya konsentris mengelilingi pusat.

Meskipun terdapat pada sisa tunggul pohon akasia yang telah ditebang, keberadaan 
tubuh buah Ganoderma sp. ini perlu diwaspadai karena jamur ini mempunyai kisaran inang yang luas. Inokulum tumbuh dan menyebar di bawah permukaan tanah, sehingga inokulumnya akan bertahan pada akar dan stump (tunggul) pohon yang sudah mati. Inokulum inilah yang banyak menyerang tanaman dikemudian hari (Old et al., 2000). Penyakit busuk akar dapat menyebar dengan melalui kontak akar tanaman yang sakit dengan akar tanaman yang sehat. Selain itu busuk akar memungkinkan tersebar melalui spora yang penyebarannya dibantu angin atau air. Spora tidak dapat menginfeksi tanaman sehat, tetapi dapat menginfeksi tonggak dari tanaman yang rentan, sehingga dapat menjadi sumber infeksi baru (Semangun, 2000). Hasil pengamatan pada penelitian menunjukkan bahwa pada musim hujan intensitas serangan penyakit sebesar $0,7 \%$ dengan luas serangan sebesar $1,53 \%$. Sedangkan saat musim kemarau tidak ditemukan gejala penyakit busuk akar pada tanaman A. auriculiformis ini.

\section{KESIMPULAN}

Jenis penyakit paling dominan menyerang tanaman $A$. auriculiformis pada dua plot pengamatan di persemaian dan bank klon di Yogyakarta adalah penyakit embun tepung dengan patogen jamur Oidium sp. Beberapa penyakit lain yang ditemukan pada plot pengamatan di bank klon adalah embun jelaga dengan patogen jamur Meliola sp, bercak daun dengan pathogen jamur Phomopsis sp. dan penyakit busuk akar dengan pathogen jamur G. steyaertanum.

\section{UCAPAN TERIMA KASIH}

Penulis mengucapkan terima kasih kepada Tim penelitian kayu energi Balai Besar Penelitian dan Pengembangan Bioteknologi dan Pemuliaan Tanaman Hutan dan semua pihak yang telah membantu dalam pelaksanaan penelitian dan penyediaan referensi dalam penulisan naskah.

\section{DAFTAR PUSTAKA}

Anggraeni, I., \& Wibowo, A. (2006). Serangan Penyakit Embun Tepung dan Karat Daun pada Acacia auriculiformis A. Cunn. Ex Benth di Kediri Jawa Timur. Jurnal Penelitian Hutan Dan Konservasi Alam, 3(1), 45-53. Retrieved from http://ejournal.fordamof.org/ejournal-

litbang/index.php/JPHKA/article/view/2898/ 2105

Barnet, H. L., \& Hunter, B. B. (1998). No Title Ilustrated Genera of Imperfect Fungi (4th ed.). Minnesota, Australia: The American Phytopathological Society St. Paul, Minnesota.

Chin, F. (1995). Damping-off in some forest nurseries in Sarawak. Forest Pathology Information, $7 \mathrm{p}$.

Cunfer, B. M. (2004). Powdery Mildew. FAO Corporate Document Repository.

Draženka, J., Karolina, V., Jasenka, Ć., Riccioni, L., \& Duvnjak, T. (2007). Morphological Identification of Diaporthe/Phomopsis sp. Isolated from Xanthium italicum. Original Scientific Paper Izvorni Znanstveni Članak, 632.4'51(4.

Giertych, M. J., \& Suszka, J. (2010). Influence of cutting off distal ends of quercus robur acorns on seedling growth and their infection by the fungus erysiphe alphitoides in different light conditions. Dendrobiology, 64(February), 73-77.

Halfeld-Vieira, B. A., \& Nechet, K. L. (2009). First report of powdery mildew of Acacia mangium in Brazil. Summa Phytopathologica, 35(3), 237.

Hendrati, R. L., Nurrohmah, S. H., Susilawati, S., \& Budi, S. (2014). Budidaya Acacia auriculiformis untuk Kayu Energi. (M. Na'iem, Mahfudz, \& S. B. Prabawa, Eds.), Agroforestry Database 4.0 (1st ed.). Bogor: IPB Press Printing. https://doi.org/10.1071/BT9930065

Hidayati, N., Glen, M., Nurrohmah, S. H., Rimbawanto, A., \& Mohammed, C. L. (2014). Ganoderma steyaertanum as a rootrot pathogen of forest trees. Forest Pathology. https://doi.org/10.1111/efp.12142

Hidayati, N., \& Nurrohmah, S. H. (2015). Karakteristik Morfologi Ganoderma steyaertanum yang Menyerang kebun Benih Acacia mangium dan Acacia auriculiformis di Wonogiri, Jawa Tengah, 9(2), 117-130. https://doi.org/doi.org/10.20886/jpth.2015.9.2 $.117-130$ 
Joker, D. (2000). Acacia auriculiformis Cunn.ex Benth. Danida Forest Seed Centre, Australia.

Old, K. M., Lee, S. S., Sharma, J. K., \& Yuan, Z. Q. (2000). A Manual of Diseases of Tropical Acacias in Australia, South-East Asia and India.

Rimbawanto, A., Tjahjono, B., \& Gafur, A. (2014). Panduan Hama dan Penyakit Akasia \& Ekaliptus. Yogyakarta: Balai Besar Penelitian Bioteknologi dan Pemuliaan Tanaman Hutan.

Semangun, H. (2000). Penyakit-penyakit tanaman perkebunan di Indonesia. Yogyakarta: Gadjah Mada University Press.

Spolti, P., Shah, D. A., Fernandes, J. M. C., Bergstrom, G. C., \& Del Ponte, E. M. (2015). Disease Risk, Spatial Patterns, and IncidenceSeverity Relationships of Fusarium Head Blight in No-till Spring Wheat Following Maize or Soybean. Plant Disease. https://doi.org/10.1094/PDIS-09-14-0944-RE
Sumartini, S., \& Rahayu, M. (2017). Penyakit embun tepung dan cara pengendaliannya pada tanaman kedelai dan kacang hijau. Jurnal Penelitian Dan Pengembangan Pertanian, $36(2)$,

59. https://doi.org/10.21082/jp3.v36n2.2017.p5966.

Thu, P. Q., Griffiths, M. W., Pegg, G. S., McDonald, J. M., Wylie, F. R., King, J., \& Lawson, S. A. (2010). Healthy plantations: A Field Guide to Pests and Pathogens of Acacia, Eucalyptus and Pinus in Vietnam. Queensland, Australia: The State of Queensland, Department of Employment, Economic Development and Innovation.

Widyastuti, S. M., \& Susanti, Z. A. (2014). Pengaruh Musim terhadap Perkembangan Atelocauda digitata, Penyebab Penyakit Karat Pada Acacia auriculiformis di Yogyakarta. Hpt, 14(1), 8-15.

www.slemankab.go.id. (2018). 
Jurnal Pemuliaan Tanaman Hutan

Vol. 12 No. 2, Desember 2018, p. 105 - 113 